\title{
Formulation, pharmacokinetics and pharmacodynamics of topical microbicides
}

\author{
Jessica L. Adams, PharmD, BCPSa, ${ }^{*}$ [HIV Pharmacology Fellow] and Angela D.M. Kashuba, \\ BScPhm, PharmD, DABCPb [Professor and Director] \\ aUniversity of North Carolina at Chapel Hill, Eshelman School of Pharmacy 3315 Kerr Hall CB\# \\ 7569, Chapel Hill, North Caroina 27599-7569, USA \\ bDivision of Pharmacotherapy and Experimental Therapeutics, Eshelman School of Pharmacy, \\ UNC Center for AIDS Research Clinical Pharmacology and Analytical Chemistry Core, University \\ of North Carolina at Chapel Hill, North Carolina, USA
}

\begin{abstract}
The development of safe topical microbicides that effectively prevent human immunodeficiency virus (HIV) infection is a major goal in curbing the human immunodeficiency virus pandemic. A number of past failures resulting from mucosal toxicity or lack of efficacy have informed the field. Products that caused toxicity to the female genital tract mucosa, and thereby increased the likelihood of HIV acquisition, included nonoxynol 9, cellulose sulfate, and C31 G vaginal gel Savvy ${ }^{\circledR}$. Topical products that were ineffective in preventing HIV infection include BufferGel ${ }^{\circledR}$, Carraguard ${ }^{\circledR}$, and PRO $2000^{\circledR}$. Antiretroviral drugs such as tenofovir and dapivirine formulated into microbicide products have shown promise, but there is much to learn about ideal product formulation and acceptability, and drug distribution and disposition (pharmacokinetics). Current formulations for water-soluble molecules include vaginally or rectally applied gels, vaginal rings, films and tablets. Dosing strategies (e.g. coitally dependent or independent) will be based on the pharmacokinetics of the active ingredient and the tolerance for less than perfect adherence.
\end{abstract}

\section{Keywords}

microbicide; pharmacokinetics; pharmacodynamics; gel; ring; film; pre-exposure prophylaxis

\section{Introduction}

In order to be effective, an ideal microbicide should not cause mucosal irritation, should distribute into the tissues that are associated with HIV transmission, be metabolised efficiently to their active components (if necessary), and achieve adequate and sustained concentrations for protection against human immunodeficiency virus (HIV) transmission. Absorption into the systemic circulation, and subsequent exposure in blood plasma, should be minimal to diminish systemic adverse effects and the potential for the virus to become drug resistant if HIV infection should occur. A microbicide must also be easy to use and well accepted by the target population. In this chapter, we discuss the lessons learned from past microbicide failures, review successes and outline current knowledge of microbicide formulations in development.

\footnotetext{
(c) 2012 Elsevier Ltd. All rights reserved.

*Corresponding author. Tel.: +1 919962 0029; Fax: +1 919962 0644. Jessica_Adams@unc.edu (J.L. Adams).

Conflict of interest

None declared.
} 


\section{Microbicide formulation}

\section{Product considerations}

Microbicide vehicles are important, as they allow the active drug to reach the proper site of activity, to distribute throughout the luminal surface (vagina or colorectum), and remain at the surfaces for an adequate (as yet undefined) period of time. Vehicles can include aqueous gels, reservoir rings, and locally applied solid films and tablets.

Physiochemical characteristics of a gel vehicle that must be optimised include volume, viscosity, yield stress, sheer rate, $\mathrm{pH}$ and osmolality. ${ }^{1}$ Reservoir rings must be formulated to provide long-term, predictable, sustained release of an active component throughout the vaginal compartment. ${ }^{2}$ Film polymers should be non-toxic, non-irritant, have adequate wetting, spreadability, disintegration over time, and strength. Solid vaginal tablets must also have adequate disintegration and dispersion throughout the vaginal compartment without causing irritation. ${ }^{1}$ For all formulations, it is important that the pharmaceutically active compound be stable in the vehicle in which it is formulated, and uniformly distributed to allow for broad distribution in the vaginal compartment. A full list of the advantages and disadvantage of each of the formulations in development is presented in Table 1.

\section{Toxicity to vaginal mucosa}

Above all, the field has learned that microbicides must demonstrate no mucosal toxicity, which can lead to irritation, epithelial disruption, release of cytokines, immune activation and changes to flora, which increase the risk of HIV acquisition. In order for a product to be compatible with the mucosal environment, physiologic $\mathrm{pH}$ must be maintained and the product should be iso-osmolar. ${ }^{3}$ Past microbicide gel failures owing to local mucosal toxicity included those containing nonoxynol $9,{ }^{4}$ cellulose sulfate,, 5 and Savvy ${ }^{\circledR} .6$ The following is a summary of the findings from those studies.

\section{Nonoxynol-9}

COL-1492 was a phase III, randomised, placebo-controlled study in 765 female sex workers using $1.5 \mathrm{~g}$ of carbomer gel (a polymer with bio-adhesive properties), containing 3.5\% nonoxynol-9 (a spermicidal surfactant). ${ }^{4}$ A $16 \%$ seroconversion rate was seen in the active arm of the study, compared with $12 \%$ in the placebo arm. Women who used the product more frequently had higher rates of HIV infection and were found more likely to have lesions with epithelial disruption. Those women reporting a mean applicator use greater than 3.5 per working day had a hazard ratio of $1.8(1.0$ to 3.2$)$ for HIV incidence $(P=0.03)$ compared with placebo. Subsequently, it was determined that nonoxynol-9 causes cytokine release, immune-cell recruitment, and alterations in vaginal flora, all of which may make women more susceptible to HIV acquisition. ${ }^{7}$ In particular, release of the cytokine interleukin-1 activates nuclear factor-kappa B, leading to chemokine-induced immune cell recruitment, which provided host cells for HIV-1 infection and increased HIV replication. ${ }^{8}$ In another study, ${ }^{9}$ after the use of nonoxynol-9 containing diaphragms, women had vaginal colonisation of Escherichia coli, Enterococcus species, and anaerobic gram-negative rods, which could also lead to immune activation and immune-cell recruitment.

\section{Cellulose sulfate}

Cellulose sulfate is a polyanion entry inhibitor with in-vitro activity against HIV-1 and HIV-2, as well as Neisseria gonorrhoeae, and Chlamydia trachomatis. ${ }^{10}$ It was found to be well tolerated in early phase safety studies using single and multiple daily doses for up to 2 weeks. ${ }^{11-14}$ A phase III study compared $3.5 \mathrm{ml}$ of $6 \%$ cellulose sulfate gel with placebo gel in 1398 women $1 \mathrm{~h}$ before intercourse. Interim analysis found 24 seroconversions in the 
cellulose sulfate arm and 11 in the placebo arm (hazard ratio 2.23; $P=0.02$ ) leading to premature discontinuation of the study. Final analysis revealed 25 out of 706 seroconversions in the cellulose sulfate arm and 16 out of 692 in the placebo arm (hazard ratio $1.61 ; P=0.13) .{ }^{5}$ Possible explanations of the results include increased inflammatory reactions and immune cell recruitment. ${ }^{15}$ Although not statistically significant, one of the safety studies had shown slightly more women with signs of increased inflammation on colposcopy after using cellulose sulfate gel twice daily for 14 days. ${ }^{16}$

\section{SAVVY ${ }^{\circledR}$}

The chemical compound $\mathrm{C} 31 \mathrm{G}\left(\mathrm{SAVVY}^{\circledR}\right)$ is a surfactant that disrupts the outer membrane of HIV with a similar mechanism to nonoxynol-9. ${ }^{17}$ In multiple phase I studies, signs of irritation with repeat dosing of $1 \% \mathrm{SAVVY}^{\circledR}$ were reported, but considered less toxic than nonoxynol $9 .{ }^{18-20}$ One colposcopy study found $1.2 \%$ SAVVY ${ }^{\circledR}$ to cause similar epithelial disruption as $2 \%$ nonoxynol- $9 .{ }^{21}$ Subsequently, a phase III study ${ }^{6}$ enrolling 2153 women using $3.5 \mathrm{ml}$ of product in a coitally dependent manner observed more seroconversions in the active arm (21 out of 1076) than in the placebo arm (12 out of 1077). The study was stopped early because of an overall lower than expected HIV incidence: mid-point analysis determined that an additional 1980 participants would be needed to reach the overall 66 events required to show efficacy. The true hazard ratio and reasons for the increased number of infections in the SAVVY ${ }^{\circledR}$ arm could not be determined. An additional parallel phase III study of 2142 women in Ghana was also stopped early because of a lower than expected HIV incidence rate. ${ }^{22}$

\section{Vivage $^{\circledR}$}

Vaginal irritation and inflammation was found to occur when $3 \%$ Vivagel $^{\circledR}$ (SPL 7013) was used twice daily for 14 days. Two out of 35 women discontinued the gel as a result of genital irritation, confirmed on colposcopy. ${ }^{23}$ A second study of 3\% Vivagel ${ }^{\circledR 24}$ evaluated inflammatory markers in the vaginal mucosa of women using the gel twice daily for 14 days. By day 7, interleukin-6, CD8+ and CD69+ cells, CD4+ and CD69+ cells and CD4+ and CCR5+ cells were all elevated $(P<0.05)$ in women using the gel compared with placebo. By day 14 , interferon gamma, interleukin-5 and interleukin-10 $(P=0.001)$ were elevated. All were reversible with discontinuation of VivaGel ${ }^{\circledR}$, and this product is continuing in Phase II studies for the treatment and prevention of bacterial vaginosis. ${ }^{25}$

\section{Lack of efficacy}

A number of topical microbicides have failed to show efficacy at preventing HIV infection, including BufferGel ${ }^{\circledR},{ }^{26}$ PRO $2000^{\circledR},{ }^{27}$ and Carraguard ${ }^{\circledR .28}$ By maintaining vaginal $\mathrm{pH} 4.0$ 4.5 in the presence of semen, BufferGel ${ }^{\circledR}$ was intended to protect against HIV infection by broadly acidifying pathogens. ${ }^{29}$ A phase II/Illb, four-arm study in 3101 women comparing BufferGel $^{\circledR}$ with $0.5 \%$ PRO $2000^{\circledR}$ gel, placebo gel, and no gel found no difference in HIV infection rates between BufferGel ${ }^{\circledR}$ and placebo gel (hazard ratio 1.10; $P=0.63$ ), and BufferGel ${ }^{\circledR}$ and no gel (hazard ratio 1.05, $\left.P=0.78\right) .{ }^{26}$ This same study showed modest benefit of a $0.5 \%$ PRO $2000^{\circledR}$ gel over placebo gel (hazard ratio $0.7, P=0.10$ ) and no gel (hazard ratio $0.67, P=0.06){ }^{26}$

PRO $2000^{\circledR}$ gel is a synthetic naphthalene sulfonate polymer that inhibits viral attachment and entry. It demonstrated antiviral activity in macaques ${ }^{30}$ and in vitro. ${ }^{31} \mathrm{~A}$ subsequent phase III study ${ }^{27}$ showed that $2 \%$ and $0.5 \%$ of PRO $2000^{\circledR}$ gel were ineffective at preventing HIV infection compared with placebo. The $2 \%$ PRO $2000{ }^{\circledR}$ gel arm was stopped prematurely due to futility, and the $0.5 \%$ PRO $2000{ }^{\circledR}$ gel arm failed to show a difference in HIV incidence compared with placebo (hazard ratio $1.05 ; P=0.71$ ). 
Carraguard ${ }^{\circledR}$ contains the polyanion carrageenan. The mechanism is not fully understood, but it may bind the positively charged regions of the viral envelope and act as a barrier to host cells. It was previously shown to prevent effectively HIV infection in vitro ${ }^{32}$ and in macaques. ${ }^{33}$ In a phase III study conducted in 6005 women in South Africa, $4 \mathrm{ml}$ of 3\% Carraguard ${ }^{\circledR}$ failed to demonstrate efficacy compared with placebo (covariate adjusted hazard ratio $0.87,95 \%$ CI 0.69 to 1.09$).{ }^{28}$

Owing to the significant number of failures of surfactants, polyanions, and general antimicrobials, a number of small molecule antiretroviral drugs are under investigation. A review of the microbicide formulations that are currently under development follows. A summary of these data are presented in Table 2 .

\section{Microbicide gels}

Antiretroviral drugs formulated as gels show promise in preventing HIV infection. Gel formulations allow for the application of antiretroviral drugs directly to the vaginal mucosa with limited systemic absorption and side-effects, and HIV resistance potential. Currently, tenofovir with and without emtricitabine, and dapivirine are being investigated in gel formulations.

\section{Tenofovir}

Tenofovir is a nucleotide reverse transcriptase inhibitor used orally in combination for the treatment of HIV- $1 .{ }^{34}$ It acts as a nucleoside analogue that terminates HIV transcription from RNA to DNA before integration into the host cell genome. ${ }^{34}$ By targeting a place in the HIV life cycle before genome integration, tenofovir could theoretically prevent initial cellular infection. Tenofovir gel has been tested in macaques, humanised mice, and in clinical studies.

Tenofovir $1 \%$ gel has been tested in macaques, with repeated exposure to the chimeric simian-human immunodeficiency virus (SHIV). In one study, $3 \mathrm{ml}$ tenofovir $1 \%$ gel given vaginally to female macaques twice weekly before SHIV challenge for a total of 20 challenges protected six out of six macaques from infection. ${ }^{35}$ Additionally, tenofovir $1 \%$ gel protected four out of six macaques against SHIV challenge 3 days after gel application. ${ }^{36}$ Rectally applied $1 \%$ tenofovir gel was shown to protect eight out of nine macaques when applied $2 \mathrm{~h}$ before simian immunodeficiency virus exposure. ${ }^{37}$

Pharmacokinetic data of both vaginal and rectally applied $1 \%$ tenofovir gel in macaques showed quick and thorough distribution throughout mucosal surfaces, with concentrations 4-5 logs higher in the mucosal compartment than in blood plasma. ${ }^{38}$

In humanised mice, topically applied tenofovir $1 \%$ gel was found to be $88 \%$ effective ( $P=$ 0.002) at preventing HIV infection compared with placebo gel when $20 \mu \mathrm{l}$ of gel was applied vaginally $4 \mathrm{~h}$ before and after HIV challenge. ${ }^{39}$

A phase I pharmacokinetic study in humans assessed 2 weeks of single and multiple dosing of once or twice daily $4 \mathrm{ml}$ applications of $1 \%$ tenofovir vaginal gel in blood plasma, endocervical cells, cervicovaginal fluid aspirates, and vaginal tissue in 49 women from the Dominican Republic and two US sites. ${ }^{40}$ Tenofovir achieved high persistent concentrations within the vaginal lumen and tissues, and minimal concentrations in the systemic circulation. No differences between proximal and distal tissue concentrations were found, demonstrating uniform distribution throughout the vagina. Cervicovaginal fluid concentrations were greater than $1,000,000 \mathrm{ng} / \mathrm{ml}$ within the first $4 \mathrm{~h}$ of dosing, and fell to $100,000 \mathrm{ng} / \mathrm{ml}$ by $24 \mathrm{~h}$. Tenofovir vaginal tissue concentrations were found to be approximately one to two logs (10 to 100 times) lower than luminal concentrations. About 
$3-5 \%$ of the tenofovir was metabolised intracellularly to the active metabolite tenofovir diphosphate, in vaginal and cervical cells within 30 mins of dosing. Blood plasma concentrations after vaginal application were less than $5 \%$ of those previously reported after oral dosing. ${ }^{41}$ These data were subsequently confirmed in an additional study using an African population. ${ }^{42}$

The vaginally formulated $1 \%$ tenofovir gel was assessed in a phase I placebo-controlled crossover study investigating rectal administration compared with oral administration of tenofovir disoproxyl fumarate. ${ }^{43}$ Eighteen healthy adults sequentially received a single dose of oral tenofovir disoproxyl fumarate $300 \mathrm{mg}$, then either $1 \%$ tenofovir gel applied rectally or a placebo gel. Rectal dosing resulted in 30 -fold lower plasma exposure than oral dosing. Ex-vivo HIV challenges were carried out on rectal biopsies obtained after 7 days of daily rectal gel use. Concentrations of the active form of the drug, intracellular tenofovir diphosphate, greater than $1000 \mathrm{fmol} / \mathrm{mg}$ were required to see significant suppression of viral replication in these tissues. As significant gastrointestinal discomfort was seen with the vaginal formulation of this gel, a rectal-specific gel with decreased osmolality has been formulated and is undergoing clinical safety and efficacy studies. ${ }^{44,45}$

Tenofovir $1 \%$ gel was the first antiretroviral to demonstrate its ability to prevent the sexual transmission of HIV. ${ }^{46}$ In the CAPRISA 004 study conducted in rural and urban sites in South Africa, ${ }^{47} 843$ women were instructed to vaginally apply $4 \mathrm{ml}$ of $1 \%$ tenofovir gel up to $12 \mathrm{~h}$ before and after sex with no more than two doses used in $24 \mathrm{~h}$. This method was proven to be $39 \%$ effective at preventing HIV infection compared with placebo overall. In women with over $80 \%$ adherence (as assessed by used applicator counts), efficacy was $54 \%$. Pharmacological analysis of cervicovaginal fluid samples found a direct correlation between higher tenofovir concentrations and protection from both HIV infection and herpes simplex 2 infection (a surprising and unexpected benefit). Kaplan-Meier analysis showed that women with cervicovaginal fluid concentrations of tenofovir less than $1000 \mathrm{ng} / \mathrm{ml}$ had an HIV incidence rate similar to that of women using placebo. Women with cervicovaginal fluid concentrations greater than $1000 \mathrm{ng} / \mathrm{ml}$ had a significantly lower chance of acquiring HIV. ${ }^{48}$

The VOICE (Vaginal plus Oral Interventions to Control the Epidemic; MTN 003) study 49 was designed to compare the efficacy of daily dosed $1 \%$ vaginal gel, a placebo gel, oral tenofovir, oral tenofovir plus emtricitabine and an oral placebo. In November 2011, the daily $1 \%$ tenofovir gel arm of the study was halted due to futility. With about 1000 women enrolled in each arm, a review of the data from September 9, 2011 to September 30, 2011 found a $6.1 \%$ infection rate in the placebo gel arm and a $6.0 \%$ infection rate in the tenofovir gel arm. The reasons for the failure of this VOICE arm after the 39\% success rate of CAPRISA 004 have yet to be determined. Limited adherence to the daily dosing of tenofovir $1 \%$ gel or increased drug exposures with the CAPRISA 004 strategy may have been factors. One additional phase III study of $1 \%$ tenofovir vaginal gel called FACTS 001 (Follow-on African Consortium for Tenofovir Studies) is currently ongoing. FACTS 001 is evaluating the effectiveness of the CAPRISA 004 dosing strategy in 2200 women in South Africa. ${ }^{50}$

\section{Dapivirine}

Because of its poor oral bioavailability, dapivirine (TMC120) is being developed solely as a topical non-nucleoside reverse transcriptase inhibitor for the prevention of HIV infection. Dapivirine allosterically blocks the reverse transcriptase enzyme and thereby prevents the complete transcription of HIV RNA to DNA. ${ }^{51}$ Dapivirine's tight binding to reverse transcriptase and high lipophilicity makes it active against both cell associated and cell free 
virus in semen without the metabolic activation that is needed for nucleotide reverse transcriptase inhibitors. 52

In animal studies, a $0.009 \%$ dapivirine vaginal gel was given over 7 days to both rabbits $(0.5$ $\mathrm{ml}$ per day) and macaques ( $1 \mathrm{ml}$ per day). Pharmacokinetic data in both species showed low plasma drug concentrations (maximum $0.225 \mathrm{ng} / \mathrm{ml}$ ). Cervical and vaginal tissue concentrations were above the in-vitro 90\% Effective Concentration (EC90) of $0.9 \mathrm{ng} / \mathrm{ml}$ for up to $48 \mathrm{~h}$ after dosing. Microautoradiography identified drug-related material on the surfaces of vaginal and cervical tissues, suggesting that the drug may reside in compromised areas of tissues and provide a protective effect at vulnerable lesions and ulcers. ${ }^{53,54}$

Dapivirine has shown to be safe and well tolerated with low systemic absorption in phase I and II studies investigating $2.5 \mathrm{ml}$ doses of $0.001,0.002,0.005$, and $0.02 \%$ dapivirine vaginal gel given twice daily for 42 days to 119 women. Plasma concentrations were dose proportional over the range studied, with no accumulation past 7 days of dosing. The maximum observed plasma concentration was a low $474 \mathrm{pg} / \mathrm{ml}$ in the $0.02 \%$ dose group. ${ }^{55}$

Dapivirine concentrations in cervicovaginal fluids and tissues were found to be well distributed throughout the vaginal compartment over 10 days of gel dosing in 18 healthy women. Women applied $2.5 \mathrm{ml}$ of either $0.001 \%, 0.005 \%$ or $0.02 \%$ dapivirine gel once daily on days 1 and 10 and twice daily on days 2 to 9 . Fluid concentrations were found to be $4.6-8.3 \times 10^{6} \mathrm{pg} / \mathrm{ml}$ on day 1 and $2.3-20.7 \times 10^{6} \mathrm{pg} / \mathrm{ml}$ on day 10 , and cervicovaginal tissue biopsies collected on day 10 had concentrations of $1.0-356 \times 10^{3} \mathrm{pg} / \mathrm{mg} .{ }^{56}$

Recently, a phase I study 57 evaluated two different formulations of $0.05 \%$ dapivirine gel for pharmacokinetics and safety. The gels were applied daily for 11 days, and both were safe and well tolerated. The maximal dapivirine plasma concentrations did not exceed $1.1 \mathrm{ng} / \mathrm{ml}$. The cervicovaginal fluid concentrations were $5 \mathrm{logs}$ higher than dapivirine's in-vitro IC50 for wild type HIV-1 virus and 3 to 5 logs higher than the in-vitro IC50 for virus containing the non-nucleoside reverse transcriptase inhibitor resistance mutation Y181C. The terminal half-life was $16-17 \mathrm{~h}$. The dapivirine gel is currently undergoing additional phase I and II studies. ${ }^{58}$

\section{Combination gel products}

Combinations of drugs formulated into a gel have a number of theoretical advantages. Combining drugs with different resistance profiles may protect against transmission of a virus with mutations to one of the agents, and may protect against rapid development of resistance if infection occurs. ${ }^{1}$ Additionally, combining drugs that act synergistically or additively may allow for lower doses of agents used in combination than used individually, thereby minimising systemic exposure and adverse effects.

Combinations currently under investigation include tenofovir with emtricitabine, and tenofovir with dapivirine. ${ }^{58}$ Macaques given $3 \mathrm{ml}$ of gel combining $1 \%$ tenofovir with 5\% emtricitabine were all protected against SHIV infection. Only $0.03 \%$ of the tenofovir dose and $0.025 \%$ of the emtricitabine dose were systemically absorbed 30 mins after gel application. ${ }^{35}$

In-vitro data suggest that dapivirine combined with tenofovir may be synergistic against transmitted viruses containing a particular non-nucleoside reverse transcriptase inhibitor mutation (Y181C). This virus is easily transmitted because it confers little or no fitness cost. $^{59}$ This study supports the hypothesis that combination microbicide products may retain antiviral activity against resistant viruses, thereby better protecting against the transmission of resistant viruses. ${ }^{60}$ 


\section{Microbicide rings}

Vaginal rings containing antiretroviral drugs are similar in concept to vaginal rings currently used for contraception and hormone replacement therapy. ${ }^{2}$ The intention of the ring is to maintain long-term, sustained antiretroviral release for local effect. Owing to the long-term drug release, rings can be used in a coitally independent manner, and only inserted monthly. This may have an adherence benefit over other microbicides in development.

\section{Dapivirine}

Dapivirine has been formulated into a ring currently undergoing phase III studies. ${ }^{58}$

Previously, two phase I studies evaluated dapivirine $25 \mathrm{mg}$ and $200 \mathrm{mg}$ delivered from a vaginal ring over 7 days in 25 healthy women. Both studies found the ring to be safe, and adverse effects similar to placebo. Mucosal fluid was sampled at $4 \mathrm{~h}, 24 \mathrm{~h}$ and 7 days after insertion in all women from the introitus, cervix and ring area, and mean drug concentrations exceeded 1000 times the EC50 against wild-type HIV-1. In both studies, the mean concentrations of dapivirine were 0.7 to $7.1 \mu \mathrm{g} / \mathrm{ml}$ in mucosal fluid, and ranged from 0.3 to $3.5 \mu \mathrm{g} / \mathrm{g}$ in cervical and vaginal tissues. The authors point out that the lowest concentration in any of the tissues sampled was over 30-fold higher than the in-vitro EC90. Plasma concentrations did not exceed $40 \mathrm{pg} / \mathrm{ml}$ with this device. ${ }^{61}$

A recent double-blind, randomised (3:1) placebo-controlled study in 48 women $^{62}$ evaluated the pharmacokinetics of multiple dosing of a $25 \mathrm{mg}$ dapivirine vaginal ring. Dapivirine concentrations and safety assessments were measured over a total of 88 days. Dapivirine concentrations peaked in vaginal fluid within the first $24 \mathrm{~h}$ after the ring was inserted. Concentrations above $0.3 \mathrm{ng} / \mathrm{ml}$ (IC50) were maintained up to 35 days. Minimum concentrations were $1.9,1.4$ and $0.7 \mu \mathrm{g} / \mathrm{g}$ measured near the ring, at the cervix and the introitus, respectively; maximum concentrations were 66.1, 58.4 and 40.1 $\mu \mathrm{g} / \mathrm{g}$. Maximal plasma concentrations were $553 \mathrm{pg} / \mathrm{ml}$. This study verified both the safety of the dapivirine ring and the ability of this product to maintain consistent drug delivery over 35 days.

\section{Combination rings}

A combination dapivirine and maraviroc ring is currently in phase $1 .^{63}$ These two antiretroviral drugs work differently: dapivirine by allosterically inhibiting reverse transcriptase, and maraviroc by preventing HIV from binding to the cell surface co-receptor CCR5. ${ }^{64}$ A dapivirine plus maraviroc combination gel has also been formulated, but studies of the gel are on hold to focus on the development of the ring formulation. ${ }^{65}$ Additionally, combining antiretroviral drugs with contraceptives into a single vaginal ring may be beneficial for women who seek protection against HIV infection while also avoiding conception. One of the largest challenges to the development of a dual releasing vaginal ring is creating differing dissolution conditions for drug entities with disparate physicochemical properties. ${ }^{66}$

\section{Microbicide films and tablets}

Intravaginal films and tablets are already used as antifungals, antibacterials, and hormone replacement products. Advantages of these dosage forms include their portability, ease of storage and ease of use. Additionally, solid dosage forms can stabilise drugs that would be otherwise degraded in an aqueous solution. Limitations include an increased risk of vaginal irritation and the need for vaginal hydration to assure uniform distribution and tissue absorption. ${ }^{1}$ 
The retrocyclin 1 peptide analog, RC-101, is currently being studied in a vaginal film formulation. This entry inhibitor prevents the binding of HIV to both CXCR4 and CCR5 coreceptors located on CD4+ cells in vitro. ${ }^{67} \mathrm{RC}-101$ is best formulated in a non-aqueous solid film dosage form because the peptide is degraded in semisolid aqueous solutions. ${ }^{68,69}$ RC-101 was formulated into a quick-dissolving $2000 \mu \mathrm{g}$ per film product and applied intravaginally to six female macaques daily for 4 days. Over this time, the peptide was detected in cytobrush and tissue samples, but not in cervicovaginal lavage or plasma. Cervical and vaginal tissues taken from two macaques one day after the last film application were protected from SHIV challenge in an ex-vivo culture system. Colposcopy revealed no mucosal changes. This study contributes to the continued development of RC-101 vaginal film. ${ }^{68}$

Other films and tablets are in early preclinical development, and include a film containing a combination of tenofovir with maraviroc, ${ }^{58}$ and a vaginal tablet containing BMS793, a gp120 mediated cell attachment inhibitor. ${ }^{58}$

\section{Conclusion}

A major advantage to the development and use of locally applied microbicides to prevent HIV infection is the ability to preclude partner negotiation, as must occur with condoms. Various topical formulations are being developed to provide a variety of options for a safe, effective, and acceptable product that can protect against HIV infection. Regardless of potency, microbicides will only be effective if they are used properly and consistently. ${ }^{70} \mathrm{~A}$ successful product rests on the ability to safely achieve adequate concentrations to prevent HIV transmission in mucosal tissues, and to maintain those concentrations throughout the window of most risk for HIV acquisition. As shown by CAPRISA 004 and VOICE, the most appropriate dosing regimen to ensure adherence, while also maintaining adequate microbicide concentrations, is yet to be determined. Just as they have for treatment, combination regimens that target different steps in the HIV life-cycle may prove most effective for prevention.

\section{Acknowledgments}

Angela Kashuba and Jessica Adams are funded by NIH 1U01AI095031-01 and CFAR 5P30AI050410-13.

\section{References}

*1. Garg S, Goldman D, Krumme M, et al. Advances in development, scale-up and manufacturing of microbicide gels, films, and tablets. Antiviral Res. 2010; 885:S19-S29. [PubMed: 21109064]

*2. Malcolm RK, Edwards KL, Kiser P, et al. Advances in microbicide vaginal rings. Antiviral Res. 2010; 885:S30-S39. [PubMed: 21109066]

3. Morris GC, Lacey Charles JN. Microbicides and HIV prevention: lessons from the past, looking to the future. Curr Opin Infect Dis. 2010; 23:57-63. [PubMed: 19918175]

4. Van Damme L, Ramjee G, Alary M, et al. COL-1492 Study Group. Effectiveness of COL-1492, a nonoxynol-9 vaginal gel, on HIV-1 transmission in female sex workers: a randomized controlled trial. Lancet. 2002; 360:971-977. [PubMed: 12383665]

5. Van Damme L, Govinden R, Mirembe FM, et al. Lack of effectiveness of cellulose sulfate gel for prevention of HIV transmission. N Engl J Med. 2008; 359:463-472. [PubMed: 18669425]

6. Feldblum PJ, Adeiga A, Bakare R, et al. Savvy vaginal gtel (C13G) for prevention of HIV infection: a randomized controlled trial in Nigeria. PLoS One. 2008; 3:e1474. [PubMed: 18213382]

7. Hillier SL, Moench T, Shattock R, et al. In vitro and in vivo: the story of nonoxynol 9. J Acquir Immune Defic Syndr. 2005; 39:1-8. [PubMed: 15851907] 
8. Fichorova RN, Tucker LD, Anderson DJ. The molecular basis of nonoxynol-9-induced vaginal inflammation and its possible relevance to human immunodeficiency virus type 1 transmission. J Infect Dis. 2009; 200:599-608. [PubMed: 19586414]

9. Gupta K, Hillier SL, Hooton TM, et al. Effects of contraceptive method on the vaginal microbial flora: a prospective evaluation. J Infect Dis. 2000; 181:595-601. [PubMed: 10669343]

10. Anderson RA, Feathergill KA, Diao XH, et al. Preclinical evaluation of sodium cellulose sulfate (Ushercell) as a contraceptive antimicrobial agent. J Androl. 2002; 23:426-438. [PubMed: 12002445]

11. Mauck C, Weiner DH, Ballagh S, et al. Single and multiple exposure tolerance study of cellulose sulfate gel: a Phase I safety and colposcopy study. Contraception. 2001; 64:383-391. [PubMed: $11834238]$

12. Doh AS, Ngoh N, Roddy R, et al. Safety and acceptability of $6 \%$ cellulose sulfate vaginal gel applied four times per day for 14 days. Contraception. 2007; 76:245-249. [PubMed: 17707724]

13. Malonza IM, Mirembe F, Nakabiito C, et al. Expanded phase I safety and acceptability study of $6 \%$ cellulose sulfate vaginal gel. AIDS. 2005; 19:2157-2163. [PubMed: 16284466]

14. El-Sadr WM, Mayer KH, Maslankowski L, et al. Safety and acceptability of cellulose sulfate as a vaginal microbicide in HIV-infected women. AIDS. 2006; 20:1109-1116. [PubMed: 16691061]

*15. Pirrone V, Wigdahl B, Krebs FC. The rise and fall of polyanionic inhibitors of the human immunodeficiency virus type 1. Antiviral Res. 2011; 90:168-182. [PubMed: 21439325]

16. Schwartz JL, Mauck C, Lai JJ, et al. Fourteen-day safety and acceptability study of $6 \%$ cellulose sulfate gel: a randomized, double-blind, Phase 1 safety study. Contraception. 2006; 74:133-140. [PubMed: 16860051]

17. Bax R, Douville K, McCormick D, et al. Microbicides-evaluating multiple formulations of C31G. Contraception. 2002; 66:365-368. [PubMed: 12443968]

18. Krebs FC, Miller SR, Catalone BJ, et al. Sodium dodecyl sulfate and C31G as microbicidal alternatives to nonoxynol 9: comparative sensitivity of primary human vaginal keratinocytes. Antimicrob Agents Chemother. 2000; 44:1954-1960. [PubMed: 10858360]

19. Mauck CK, Weiner DH, Creinin MD, et al. A randomized Phase I vaginal safety study of three concentrations of C31G vs. Extra strength gynol II. Contraception. 2004; 70:233-240. [PubMed: 15325893]

20. Mauck CK, Creinin MD, Barnhart KT, et al. A Phase I comparative postcoital testing study of three concentrations of C31G. Contraception. 2004; 70:227-231. [PubMed: 15325892]

21. Ballagh SA, Baker JM, Henry DM, et al. Safety of single daily use for one week of C31G HEC gel in women. Contraception. 2002; 66:369-375. [PubMed: 12443969]

22. Peterson L, Nanda K, Opoku BK, et al. SAVVY (C31G) gel for prevention of HIV infection in women: a Phase 3 double-blind, randomized, placebo-controlled trial in Ghana. PLoS One. 2007; 2:e1312. [PubMed: 18091987]

23. McGowan I, Gomez K, Bruder K, et al. Phase 1 randomized trial of the vaginal safety and acceptability of SPL7013 gel (VivaGel) in sexually active young women (MTN-004). AIDS. 2011; 25:1057-1064. [PubMed: 21505316]

24. Moscicki AB, Kaul R, Yifei, et al. Measurement of muscosal biomarkers in a phase 1 trial of intravaginal 3\% SPL 7013 (VivaGel ${ }^{\circledR}$ ) to assess expanded safety. J Acquir Immune Defic Syndr. 2011 epub ahead of print.

25. Starpharma Holdings Limited. Vivage ${ }^{\circledR}$ [homepage on the Internet]. Victoria, Australia: 2011. http://www.starpharma.com/vivagel [accessed 15.01.12]

26. Abdool Karim SS, Richardson BA, Ramjee G, et al. Safety and effectiveness of BufferGel and $0.5 \%$ PRO2000 gel for the prevention of HIV infection in women. AIDS. 2011; 25:957-966. [PubMed: 21330907]

27. McCormack S, Ramjee G, Kamali A, et al. PRO2000 vaginal gel for prevention of HIV-1 infection (Microbicides Development Programme 301): a phase 3, randomized, double-blind, parallel-group trial. Lancet. 2010; 376:1329-1337. [PubMed: 20851460]

28. Skoler-Karpoff S, Ramjee G, Ahmed K, et al. Efficacy of Carraguard for prevention of HIV infection in women in South Africa: a randomized, double-blind, placebo-controlled trial. Lancet. 2008; 372:1977-1987. [PubMed: 19059048] 
29. Olmsted SS, Dubin NH, Cone RA, et al. The rates at which human sperm are immobilized and killed by mild acidity. Fertil Steril. 2000; 73:687-693. [PubMed: 10731526]

30. Rusconi S, Moonis M, Merrill DP, et al. Naphthalene sulfonate polymers with CD4-blocking and anti-human immunodeficiency virus type 1 activities. Antimicrob Agents Chemother. 1996; 40:234-236. [PubMed: 8787913]

31. Weber J, Nunn A, O'Connor T, et al. 'Chemical condoms' for the prevention of HIV infection: evaluation of novel agents against SHIV(89.6PD) in vitro and in vivo. AIDS. 2001; 15:15631568. [PubMed: 11504989]

32. Pearce-Pratt R, Phillips DM. Sulphated polysaccharides inhibit lymphocyte-to-epithelial transmission of HIV. Biol Reprod. 1996; 54:173-182. [PubMed: 8838015]

33. Turville SG, Aravantinou M, Miller T, et al. Efficacy of Carraguard-based microbicides in vivo despite variable in vitro activity. PLoS One. 2008; 3:e3162. [PubMed: 18776937]

34. Viread (package insert). Foster City, CA: Gilead Sciences, Inc; 2011.

35. Parikh UM, Dobard C, Sharma S, et al. Complete protection from repeated vaginal simian-human deficiency virus exposures in macaques by topical gel containing tenofovir alone or with emtricitabine. J Virol. 2009; 83:10358-10365. [PubMed: 19656878]

*36. Dobard C, Sharma S, Martin A, et al. Durable protection from vaginal SHIV infection in macaques by tenofovir gel and its relationship to tissue drug levels. J Virol. 2012; 86:718-725. [PubMed: 22072766]

37. Cranage M, Sharpe S, Herrera C, et al. Prevention of SIV rectal transmission and priming of T cell responses in macaques after local pre-exposure application of tenofovir gel. PLoS Med. 2008; 5:e157. [PubMed: 18684007]

38. Nuttall J, Kashuba A, Wang R, et al. Pharmacokinetics of tenofovir following intravaginal and intrarectal administration of tenofovir gel to rhesus macaques. Antimicrob Agents Chemother. 2012; 56:103-109. [PubMed: 21986823]

39. Denton PW, Othieno F, Martinez-Torres F, et al. Topically applied $1 \%$ tenofovir in humanized BLT mice using the CAPRISA 004 experimental design demonstrates partial protection from vaginal HIV infection validating the BLT model for the evaluation of new microbicide candidates. J Virol. 2011; 85:7582-7593. [PubMed: 21593172]

*40. Schwartz J, Rountree W, Kashuba ADM, et al. A multi-compartment, single and multiple dose pharmacokinetic study of the vaginal candidate microbicide $1 \%$ tenofovir gel. PLoS One. 2011; 6:e25974. [PubMed: 22039430]

41. Hoetelmans RMW, Marien K, De Pauw M, et al. Pharmacokinetic interaction between TMC114/ ritonavir and tenofovir disoproxil fumarate in healthy volunteers. Br J Clin Pharmacol. 2007; 64:655-661. [PubMed: 17610528]

42. Hendrix, C.; Minnis, A.; Guddera, V., et al. MTN-001: a phase 2 cross-over study of daily oral and vaginal TFV in healthy, sexually active women results in significantly different product acceptability and vaginal tissue drug concentrations. 18th Conference on Retroviruses and Opportunistic Infections; 27 Feb-2 Mar 2011; Boston, MA. Paper \#35LB

43. Anton, P.; Cranston, R.; Carballo-Diequez, A., et al. RMP-02/MTN-006: A phase 1 placebocontrolled trial of rectally applied $1 \%$ vaginal TFV gel with comparison to oral TDF. 18th Conference on Retroviruses and Opportunistic Infections; 27 Feb-2 Mar 2011; Boston, MA. Paper \#34LB

44. Dezzutti, CS.; Rohan, LC.; Lynam, JD., et al. Tenofovir Gel Reformulation Results in Improved Product Safety for Rectal Application. 18th Conference on Retroviruses and Opportunistic Infections; 27 Feb-2 Mar 2011; Boston, MA. Paper \#983

45. Microbicide Trials Network. [accessed 15.01.12] MTN-007: Phase I Tenofovir gel rectal safety study. http://www.mtnstopshiv.org/news/studies/mtn007

*46. Abdool Karim Q, Abdool Karim SS, Frohlich JA, et al. Effectiveness and safety of Tenofovir Gel, an antiretroviral microbicide, for the prevention of HIV infection in women. Science. 2010; 329:1168-1174. [PubMed: 20643915]

47. Kashuba, ADM.; Abdool Karim, SS.; Kraft, E., et al. Do systemic and genital tract tenofovir concentrations predict HIV seroconversion in the CAPRISA 004 tenofovir gel trial?. XVIII International AIDS Conference; Vienna, Austria. 18-23 Jul 2011; p. Abstract TUSS0502 
*48. Abdool Karim SS, Kashuba ADM, Werner L, Abdool Karim Q. Drug concentrations after topical and oral antiretroviral pre-exposure prophylaxis: implications for HIV prevention in women. Lancet. 2011; 378:279-281. [PubMed: 21763939]

49. Microbicide Trials Network. [accessed 15.01.12] MTN statement on decision to discontinue use of tenofovir gel in VOICE, a major HIV prevention study in women. Immediate press release 25 Nov 2011; http://www.mtnstopshiv.org/node/3909

50. FACTS Consortium. [accessed 15.01.12] FACTS 001 study design. http://www.factsconsortium.co.za/

51. Das K, Clark AD Jr, Lewi PJ, et al. Roles of conformational and positional adaptability in structure-based design of TMC125-R165335 (etravirine) and related nonnucleoside reverse transcriptase inhibitors that are highly potent and effective against wild-type and drug-resistant HIV-1 variants. J Med Chem. 2004; 47:2550-2560. [PubMed: 15115397]

52. D’Cruz OJ, Uckun FM. Dawn of non-nucleoside inhibitor based anti-HIV microbicides. J Antimicrob Chemother. 2006; 57:411-423. [PubMed: 16431862]

*53. Nicol MR, Kashuba ADM. Pharmacologic opportunities for HIV prevention. Clin Pharmacol Ther. 2010; 88:598-609. [PubMed: 20881955]

54. Nuttall JP, Thake DC, Lewis MG, et al. Concentrations of dapivirine in the rhesus macaque and rabbit following once daily intravaginal administration of a gel formulation of [14C]dapirivine for 7 days. Antimicrob Agents Chemother. 2008; 53:487-495. [PubMed: 19029331]

55. Nel AM, Coplan P, van de Wijgert JH, et al. Safety, tolerability, and systemic absorption of dapivirine vaginal microbicide gel in healthy, HIV-negative women. AIDS. 2009; 23:1531-1538. [PubMed: 19550287]

56. Nel AM, Coplan P, Smythe SC, et al. Pharmacokinetic assessment of dapivirine vaginal microbicide gel in healthy, HIV-negative women. AIDS Res Hum Retroviruses. 2010; 26:11811190. [PubMed: 20854207]

57. Nel AM, Smythe SC, Habibi S, et al. Pharmacokinetics of 2 dapivirine vaginal microbicide gels and their safety Vs. hydroxyethyl cellulose-based universal placebo gel. J Acquir Immune Defic Syndr. 2010; 55:161-169. [PubMed: 20574411]

58. International Partnership for Microbicides. IPM Product Pipeline. Silver Spring, MD: http:// www.ipmglobal.org/products-development [accessed 15.01.12]

59. Soares EA, Santos AF, Sousa TM, et al. Differential drug resistance acquisition in HIV-1 of subtypes B and C. PLoS One. 2007; 2:e730. [PubMed: 17710130]

60. Schader SM, Colby-Germinario SP, Schachter J, et al. Synergy against drug-resistant HIV-1 with the microbicide antiretrovirals, dapivirine and tenofovir, in combination. AIDS. 2011; 25:15851594. [PubMed: 21633286]

61. Romano J, Variano B, Coplan P, et al. Safety and availability of dapivirine (TMC120) delivered from an intravaginal ring. AIDS Res Hum Retroviruses. 2009; 25:483-488. [PubMed: 19388819]

62. Nel, A.; Habibi, S.; Smythe, S., et al. Pharmacokinetics and Safety Assessment of Monthly AntiHIV DPV Vaginal Microbicide Rings with Multiple Dosing. 18th Conference on Retroviruses and Opportunistic Infections; February 27-March 2, 2011; Paper \#1001

63. Microbicide Trials Network. [accessed 15.01.12] MTN-013/IPM 026: Phase 1 Safety and Pharmacokinetics of Dapivirine/Maraviroc Intravaginal Ring. http:/www.mtnstopshiv.org/studies/ 2241

64. Selzentry (package insert). Research Triangle Park, NC: ViiV Healthcare; 2010.

65. ClinicalTrials.gov. A safety and pharmacokinetic study for dapvirine and maraviroc gel in Belgium. ClinicalTrials.gov; Identifier: NCT01242579; http://clinicaltrials.gov/ct2/show/ NCT01242579 [accessed 15.01.12]

*66. Friend DR, Doncel GF. Combining prevention of HIV-1, other sexually transmitted infections and unintended pregnancies: development of dual-protection technologies. Antiviral Res. 2010; 885:s47-s54. [PubMed: 21109068]

67. Cole AM, Hong T, Boo LM, et al. Retrocyclin: a primate peptide that protects cells from infection by T- and M-tropic strains of HIV-1. Proc Natl Acad Sci U S A. 2002; 99:1813-1818. [PubMed: 11854483] 
68. Cole AM, Patton DL, Rohan LC, et al. The formulated microbicide RC-101 was safe and antivirally active following intravaginal application in pigtailed macaques. PLoS One. 2010; 5:e15111. [PubMed: 21124745]

69. Sassi AB, Cost MR, Cole AL, et al. Formulation development of retrocyclin 1 analog RC-101 as an anti-HIV vaginal microbicide product. Antimicrob Agents Chemother. 2011; 55:2282-2289. [PubMed: 21321138]

*70. Kashuba ADM, Patterson KB, Dumond JB, et al. Pre-exposure prophylaxis for HIV prevention: how to predict success. Lancet. 2011 epub ahead of print. 


\section{Practice points}

- An optimal microbicide formulation must be discrete, easy to use, safe for mucosal tissues, stable under a variety of climate conditions, and distribute evenly.

- Product acceptability is critical for optimal adherence because no HIV prevention method will be effective if the target population does not find it easy to use.

- Drug concentrations protective of HIV infection in mucosal tissues have yet to be determined; the pharmacokinetics and drug exposure will dictate optimal dosing regimens. 


\section{Research agenda}

- Pharmacokinetic exploration of differing results between CAPRISA 004 and VOICE.

- Clinical studies of dapivirine gel and ring.

- Drugs with mechanisms other than reverse transcription inhibition, such as entry inhibitors and integrase inhibitors.

- Combination antiretroviral gel and ring products.

- Continued efficacy end points with gel and ring formulations.

- Development of unique formulations, such as films and tablets.

- Combining HIV protection with contraceptive products. 
Table 1

Advantages and disadvantages of microbicide formulations.

\begin{tabular}{|c|c|c|}
\hline Formulation & Advantages & Disadvantages \\
\hline Gels & $\begin{array}{l}\text { Female controlled. } \\
\text { Discrete. } \\
\text { Lubricating properties. } \\
\text { Limited systemic absorption. } \\
\text { Low side-effect potential. }\end{array}$ & $\begin{array}{l}\text { Effective compound must be stable in aqueous solution } \\
\text { Stability. } \\
\text { Applicators required. } \\
\text { Leaking is possible. } \\
\text { Frequent application may be required. } \\
\text { Adherence disadvantage. } \\
\text { Uneven distribution possible, depending on gel properties. }\end{array}$ \\
\hline Rings & $\begin{array}{l}\text { Female controlled. } \\
\text { Discrete. } \\
\text { No applicator required. } \\
\text { No leakage } \\
\text { Long term. } \\
\text { Adherence benefit. } \\
\text { Limited systemic absorption. } \\
\text { Low side-effect potential. } \\
\text { Can be combined with contraception. }\end{array}$ & $\begin{array}{l}\text { Sustained delivery must occur. } \\
\text { Distribution may not be uniform throughout genital } \\
\text { compartment. } \\
\text { May be uncomfortable or difficult to insert for some. } \\
\text { More complex manufacturing. }\end{array}$ \\
\hline Films and tablets & $\begin{array}{l}\text { Female controlled. } \\
\text { Discrete. } \\
\text { No applicator needed. } \\
\text { Viable option for drugs that would be degraded in aqueous } \\
\text { solution. } \\
\text { Could be formulated for immediate for timed release. } \\
\text { No leakage. } \\
\text { Low side-effect potential. } \\
\text { Can be combined with contraception. }\end{array}$ & $\begin{array}{l}\text { Absorption may be dependent upon local hydration. } \\
\text { Local irritation could result from contact with solids. } \\
\text { Concern for uniformity of distribution. }\end{array}$ \\
\hline
\end{tabular}


Table 2

Human microbicide data for products in development.

\begin{tabular}{|c|c|c|c|}
\hline Study & Product/formulation & Methods & Efficacy and pharmacokinetic \\
\hline \multicolumn{4}{|c|}{ Tenofovir with or without emtricitabine } \\
\hline Schwartz et al. ${ }^{40}$ & Tenofovir $1 \%$ gel. & $\begin{array}{l}\text { Single and multiple dosing of } \\
\text { once or twice daily } 4 \mathrm{ml} \\
\text { applications for } 2 \text { weeks in } 49 \\
\text { women. }\end{array}$ & $\begin{array}{l}\text { Concentrations ranged from } 1.2 \times 10^{4} \text { to } 9.9 \times 10^{6} \mathrm{ng} / \\
\text { ml after a single dose, and } 2.1 \times 10^{2} \text { to } 1.4 \times 10^{6} \mathrm{ng} / \mathrm{ml} \\
\text { after multiple dosing in fluid samples with no difference } \\
\text { in concentrations between proximal and distal tissues. } \\
\text { Tenofovir diphosphate levels ranged from } 7.1 \times 10^{3} \text { to } \\
8.8 \times 10^{6} \mathrm{ng} / \mathrm{ml} \text { in endocervical cells, and drug } \\
\text { concentrations were minimal in blood plasma with a } \\
\text { median maximum concentration of } 4.0 \mathrm{ng} / \mathrm{ml} \text { after a } \\
\text { single dose and } 3.4 \mathrm{ng} / \mathrm{ml} \text { after multiple dosing. }\end{array}$ \\
\hline $\begin{array}{l}\text { Hendrix et al. }{ }^{42} \\
\text { MTN } 001\end{array}$ & $\begin{array}{l}\text { Tenofovir } 1 \% \text { gel, } \\
\text { tenofovir oral tablet, or } \\
\text { both. }\end{array}$ & $\begin{array}{l}\text { Crossover design to compare } \\
\text { acceptability, tolerability and } \\
\text { pharmacokinetics in } 144 \\
\text { women. Daily doses of either } \\
\text { oral tenofovir, tenofovir gel, or } \\
\text { both, were administered daily } \\
\text { for } 6 \text { weeks in each period. }\end{array}$ & $\begin{array}{l}\text { African women preferred the gel form; American } \\
\text { women preferred the oral form; most adverse effects } \\
\text { were associated with oral tenofovir. Tissue } \\
\text { concentrations of the active tenofovir triphosphate were } \\
2352 \mathrm{fmol} / \mathrm{mg} \text { after gel administration compared with } \\
17 \mathrm{fmol} / \mathrm{mg} \text { after oral administration. Peripheral blood } \\
\text { mononuclear cell tenofovir-diphosphate concentrations } \\
\text { were } 52 \mathrm{fmol} / \mathrm{million} \text { cells after oral administration and } \\
5 \mathrm{fmol} / \mathrm{million} \text { cells after gel administration. }\end{array}$ \\
\hline
\end{tabular}

Anton et al. ${ }^{43}$ MTN Tenofovir $1 \%$ gel.

006

$\begin{array}{lll}\text { Abdool Karim et } & \text { Tenofovir 1\% gel. } & 843 \text { women used one } \\ \text { al. }{ }^{26} \text { CAPRISA004 } & & \text { application }(4 \mathrm{ml} \text { ) of gel up to } \\ & 12 \mathrm{~h} \text { before and after sex for an } \\ & \text { average of } 18 \text { months of follow } \\ & \text { up. }\end{array}$

VOICE $^{49}$

FACTS $^{50}$

Dapivirine

$\mathrm{Nel}$ et al. ${ }^{55}$

Nel et al. ${ }^{56}$

Nel et al. ${ }^{57}$

Romano et al. ${ }^{61}$
Tenofovir $1 \%$ gel; tenofovir $300 \mathrm{mg}$ oral tablet; tenofovir plus emtricitabine oral tablet.

Tenofovir $1 \%$ gel.

Dapivirine $0.001 \%$, $0.002 \%, 0.005 \%, 0.02 \%$ gel.

Dapivirine $0.001 \%$, $0.005 \%, 0.02 \%$ gel

$2.5 \mathrm{ml}$ applied vaginally in 18 women for 10 days; once daily on days 1 and 10 and twice daily on days $2-9$.

Dapivirine $0.05 \%$ gel.

$2.5 \mathrm{~g}$ applied vaginally daily for 11 days in 36 women.

Dapivirine $25 \mathrm{mg}$, and $200 \mathrm{mg}$ ring. Once-daily dosing in 5000 women (approximately 1000 women in the gel arm).

Approximately 2200 women randomly assigned to tenofovi gel or placebo gel used one application of gel up to $12 \mathrm{~h}$ before and after sex $2.5 \mathrm{ml}$ applied vaginally twice
daily for 42 days in 119 women

25 women inserted the ring for 7 days, with blood plasma and a single participants received then a single dose of either vaginally formulated gel used rectally or placebo gel rectally (2:1), followed by 7 days of

n.

All doses were found to be safe, with dose proportional plasma concentrations across the dosing range. The maximum observed plasma concentration was $474 \mathrm{pg}$ / $\mathrm{ml}$ in the $0.02 \%$ dose group.

All doses were safe and well tolerated. Mean peak values in cervicovaginal fluid were $4.6-8.3 \times 10^{6} \mathrm{pg} / \mathrm{ml}$ on day 1 and $2.3-20.7 \times 10^{6} \mathrm{pg} / \mathrm{ml}$ on day 10 . Dapivirine concentrations in vaginal tissue biopsies collected at day 10 were $1.0-356 \times 10^{3} \mathrm{pg} / \mathrm{mg}$.

Cervicovaginal fluid concentrations were at least $5 \operatorname{logs}$ higher than the in-vitro inhibitory concentrations and maximum plasma concentrations did not exceed $1.1 \mathrm{ng} /$ $\mathrm{ml}$. vaginal fluid sampling from the introitus, cervix, and ring area.
Both concentrations of rings were found to have concentrations throughout the genital tract that exceeded 1000 times the EC50. The lowest

concentration in any of the tissue samples was over 30- 


\begin{tabular}{|c|c|c|c|}
\hline Study & Product/formulation & Methods & Efficacy and pharmacokinetic \\
\hline & & & $\begin{array}{l}\text { fold higher than the in-vitro EC } 90 . \text { Mean plasma } \\
\text { concentrations were less than } 50 \mathrm{pg} / \mathrm{ml} \text {. }\end{array}$ \\
\hline Nel et al. ${ }^{62}$ & Dapivirine 25 mg Ring. & $\begin{array}{l}48 \text { women randomised ( } 3: 1) \text { to } \\
\text { dapivirine ring or placebo ring. } \\
\text { Group A inserted a first ring for } \\
28 \text { days then a second ring on } \\
\text { day } 31 \text { for another } 28 \text { days. } \\
\text { Group B inserted a first ring for } \\
35 \text { days, then a second ring on } \\
\text { day } 38 \text { for } 21 \text { days, then a third } \\
\text { ring on day } 59 \text { for } 24 \mathrm{~h} \text {. }\end{array}$ & $\begin{array}{l}\text { Dapivirine drug concentrations in vaginal fluid peaked } \\
\text { within } 24 \text { h remained consistent for up to } 35 \text { days at } \\
\text { levels well above the IC50, with even distribution } \\
\text { throughout the genital tract. The maximum plasma } \\
\text { concentration measured was } 553 \mathrm{pg} / \mathrm{ml} \text {. }\end{array}$ \\
\hline
\end{tabular}

